\title{
Liddle syndrome
}

INSERM

\section{Source}

INSERM. (1999). Orphanet: an online rare disease and orphan drug data base. Liddle syndrome. ORPHA:526

Liddle syndrome is a rare inherited form of hypertension characterized by severe earlyonset hypertension associated with decreased plasmatic levels of potassium, renin and aldosterone. 